Adrian Martin's book The Mad Max Movies is the second in a new series of monographs published by Currency Press and ScreenSound Australia. ${ }^{1}$ Like the BFI Classics and Modern Classics published by the British Film Institute, this series of books, titled Australian Screen Classics, aims to appeal to both academic and non-academic readerships. While the com-

\title{
the aesthetics of
} action film-making

ADRIAN MARTIN

The Mad Max Movies

Currency Press and ScreenSound Australia, Sydney, 2003

ISBN 0-86-19-670-3

RRP $\$ 14.95(\mathrm{pb})$ missioned writers don't shun the theoretical, cultural-historical and political approaches to the study of film found in books published by academic presses, they certainly have a facility for making difficult and sometimes contentious ideas accessible to a wider audience. In her introduction to the series, commissioning editor Jane Mills writes, 'All we ask of our writers is that they feel passionate about the films they choose'. (vi) Whether writing film reviews for the Age newspaper or longer review essays for publications such as Senses of Cinema and Sight and Sound, Martin has always made this passionately felt engagement with film the basis of his own critical practice.

Of course, simply feeling passionate about film isn't any kind of guarantee of lively, thoughtprovoking film criticism. What makes Martin's writing on film always worth reading is that the personal-polemical dimensions of his criticism and analysis-for example, the expressions of taste (and distaste) or the exercise of ethical or political judgments-also have a social and even pedagogical dimension. The idea that what separates good criticism from bad is the extent to which personal judgments come out of, or enter into, wider cultural issues and debates is one that Martin has broached in a number of ways and contexts over the years, but most 
recently and directly in a review of David regard Mad Max as the freshest, most challengThomson's The New Biographical Dictionary of ing and least appreciated entry in the cycle'. (7) Film. ${ }^{2}$ Here he takes Thomson to task for failing A little later he refers to it as 'Australia's greatest to keep pace with new ideas and new filmmaking and, as a result, for failing to provoke B movie'. (14) and challenge his readers. There was a time, be entirely surprised by this discovery. His at Martin suggests, when Thomson 'would have times wonderfully unbridled expressions of known that, especially when addressing a loathing for middlebrow aesthetic values have, general audience, one should not flatter widely after all, provided opportunity enough for held preconceptions and prejudices, but smash appreciative snorting from readers in the past. them, violently or gently, and then try to open There is, then, something familiar about his out the cultural horizon'. (11) It's this kind of siding with Mad Max against those middlebrow uncompromising approach to his craft, this critics who dismissed it as unworthy of aesinsistence on bringing pressure to bear on thetic attention and appraisal first time around. habitual ways of thinking about film, that 'Any film that hails from the B-exploitation genre Martin brings to his reassessment of the Mad corral is', he suggests, 'invariably a challengeMax series. if not an affront-to middlebrow aesthetic

Martin's comments on the way his own appreciation of these films have changed over the course of writing the book recall Stanley Cavell's defense of the speculative and provisional nature of film criticism that ventures to offer any kind of 'reading'. A 'reading', Cavell explains, 'is a term I use in part to suggest that the next time I speak about the subject it will probably go differently'. ${ }^{3}$ Returning to these films more than twenty years after the original Mad Max (1979) was released, Martin finds himself revising previously held opinions. Whereas Mad Max 2 (1981) had once seemed to be the most interesting and vital of the trio, it now seems to him to be uninspiring and dated, its importance resting largely on the esteem in which it is held by audiences and film-makers both nationally and internationally. Its predecessor, on the other hand, proves to be a revelation: 'I have come', Martin writes, 'to values'. (16) It's Martin's wide-ranging interest in developing an understanding of 'popular', as opposed to what might be called 'cult' aesthetic values, however, that distinguishes him from those critics who Andrew Sarris once identified as indulging 'the classic highbrow gambit of elevating lowbrow art at the expense of middlebrow art'. ${ }^{4}$ As Martin has often enough pointed out, what the cult cinema paramour shares with the middlebrow critic is the smug certainty that popular genre film is just too commercial and formulaic to even be discussed in aesthetic terms. ${ }^{5}$ In the case of Mad Max, his pitting of lowbrow against middlebrow aesthetic values also has a very specific institutional formation in its sights: that is, the tired old tethering of national cinema to discourses of 'quality'. While it has been a while since this kind of thinking has had any currency in academic writing on Australian cinema, it is, as Martin points out, 
still far from becoming extinct in our daily newspapers.

One of the things that this book wants to say is that if you're serious about engaging with what makes popular films appealing-with what gives them aesthetic value-then you will want to examine them pretty closely. In Martin's own words:

Any fan, theorist or filmmaker who makes the effort to really get inside the momentby-moment mechanics of these films will discover how richly they reward stop-frame analysis. Conversely, the further that discussions of the Mad Max series get from the nitty-gritty fine grain of images, sounds, cuts and formal structures, the less persuasive and convincing their arguments become. (6)

Here Martin doesn't have in mind those readings of the Mad Max series that have focused, as Ross Gibson for instance has, on its spectacularly irreverent re-imagining of the Australian landscape, pointing to all the ways in which this landscape has been envisaged as a fantastic and mutable space that is very different to the realist and historically unchanging place it occupies in so many other Australian films. Nor is he thinking of Meaghan Morris's suggestion that what is uncanny about these films is the way in which their stories of a fantastic future can also be understood to be haunted by the terrible events of a real Australian past. In other words, his advocating of a mode of reading 'more akin to '70s style textual analysis' is not addressed to the kinds of cul- tural readings that try to connect a line of thinking in a film to just some of the other myriad stories and images that give it historical resonance. Indeed, the importance of these readings for his own thinking about this series is acknowledged throughout the book. Instead, it is those readings that approach the Mad Max films thematically, connecting their heroic narratives to familiar myths and archetypes that, for Martin, risk missing the point: that the real 'power and importance' of Mad Max lies in the film's 'remarkable action scenes' (20-1).

Martin's engagement with the nitty-gritty of the film's action cinematography and editing is a highlight of the book. In his detailed analysis of the way a particular scene has been designed to bring viewers into the terror of the moment 'inch by inch, shot by shot, set-up by set-up' or in his identification of the film's technique of creating shock for viewers by zooming into an oncoming object or terrified face right in 'the midst of an already chaotically mobile, highspeed scene', Martin skillfully illuminates the craftiness and appeal of this type of film-making $(13,23-4)$. Like the best of this type of criticism, Martin's close analyses of technique link the film to other films and film-makers, so that innovations in technique in fact become the site for thinking about the film historically.

The book's emphasis on thinking about the aesthetics of action film-making-an aesthetics, which, Martin argues, shifts throughout the series to become more experimental and 'arty' with each new instalment-also provides the opportunity for reflecting on viewers' experiences of this kind of cinema. The cognitivist emphasis of much recent film scholarship comes 
under particular scrutiny. In referring to this scholarship, Martin has in mind work such as David Bordwell's recent study of Hong Kong cinema, but other writers associated with this approach to theorising cinema spectatorship include Kristen Thompson, Warren Buckland and Stephen Prince. ${ }^{6}$ The emphasis in these writers' work on describing the ways in which films address viewers as knowledgeable, active participants in their unfolding dramas, inviting them to engage in activities such as anticipating and predicting what will happen next, has, Martin suggests, been at the expense of trying to account for the unconscious dimensions of film viewing. Without wanting to give up these kinds of observations himself, Martin's readings of the Mad Max films also try to make space for speculating on the way that the shocks of action and horror film-making address the body and the emotions, provoking involuntary memories and the activation of violent fantasy.

One of the ways in which the 'cognitivist' approach to theorising film spectatorship has been important - and the reason it has been particularly productive for scholars working at the film-cultural studies nexus-is that it acknowledges that for all kinds of viewers (fans, cinephiles, film students, and the growing number of DVD collectors) knowing about cinema is important. Of course, as time goes by, it seems more and more important to be able to think about the many different ways that films engage their audiences and on this score, as this book suggests, no single model will quite do. At less than ninety pages long, The Mad Max Movies is a gulp of a read, but Martin is no 'backsliding cinephile', so you can also expect to want to dip back into it again and again.

MICHELE PIERSON teaches film and television studies at the University of Queensland and is the author of Special Effects: Still in Search of Wonder (Columbia University Press, New York, 2002).

1. Other books in the series include Louis Nowra, Walkabout, and Christos Tsiolkas, The Devil's Playground.

2. Adrian Martin, 'Chronicle of a Backsliding Cinephile, or the Two Daves', Cineaste, vol. 28, no. 3, Summer 2003, p. 11.

3. Stanley Cavell, Contesting Tears: The Hollywood Melodrama of the Unknown Woman, University of Chicago Press, Chicago, 1996, p. xi.

4. Andrew Sarris, The American Cinema, E.P. Dutton, New York, 1968, p. 29.

5. See, for instance, Adrian Martin's Phantasms, McPhee Gribble/Penguin Books, Melbourne, 1994.

6. David Bordwell, Planet Hong Kong: Popular Culture and the Art of Entertainment, Harvard University Press, Cambridge, 2000. 